\title{
A Study on Poverty and Hunger in India
}

\author{
Junofy Anto Rozarina. N. \\ Department of Economics, \\ Central University of Tamilnadu, Thiruvarur, India
}

\section{Doi:10.5901/mjss.2013.v4n12p147}

\begin{abstract}
Poverty is not simply a lack of adequate income. It is a social phenomenon in which a section of a society is unable to fulfil even its basic necessities of life. Even with more than a thousand analysis and hundreds of programs to alleviate poverty, the level of poverty has not decreased up to the mark in the world. India is continuing to face this issue in spite of its development in many areas of operation. Article 25 (1) of the Universal Declaration of Human Rights of United Nations ${ }^{1}$ states that "Everyone has the right to a standard of living adequate for the health and well-being of himself and of his family, including food, clothing, housing and medical care and necessary social services". This right is further reaffirmed in the International Covenant on Economic, Social and Cultural Rights and the International Covenant on Civil and Political Rights. But this basic right is not conferred on many people. The Human Development Indicator shows that India stands in the $136^{\text {th }}$ position among 186 countries with an index of 0.554 and is in the lowest ebb of the Medium Human Development. Hence this paper intends to study the intensity of poverty and hunger in India by appraising the indices like Global Hunger Index, Below Poverty Line Index and Multidimensional Poverty Index calculated by various global institutions. The Human Poverty Index (HPI) uses indicators of the most basic dimensions of deprivation of human life already reflected in the HDI like longevity or survival, knowledge and a decent standard of living. Hence this study studies the Multidimensional Poverty Index, which also reflects the HDI.
\end{abstract}

\section{Poverty in the World}

Poverty is wide spread in this world with over 3 billion people living on less than $\$ 2.50$ a day ${ }^{2}$. The inequality can be emphasized from the fact that the GDP (Gross Domestic Product) of the 41 Heavily Indebted Poor Countries (567 million people) is less than the wealth of the world's top seven richest people combined. Due to severe hunger and malnutrition, 10.6 million died in 2003 before they reached the age of 5 (or roughly 29,000 children per day). Almost half the world - over three billion people live on less than $\$ 2.50$ a day and at least $80 \%$ of humanity lives on less than $\$ 10$ a day.

\section{Poverty in South Asi}

South Asia is the developing sub-region with the largest number of poor people. 43 per cent of the world's 1.4 billion poor people live in South Asian countries. The absolute number of people living in extreme poverty increased from 548.3 million to 595.6 million between 1981 and $2005^{3}$.

\footnotetext{
${ }^{1}$ General Assembly resolution 217 A (III) of 10 December 1948.

2 Human Development Report, UNDP

${ }^{3}$ Rethinking Poverty, Report on the World Social Situation 2010, Department of Economic and Social Affairs, United Nations publication, United Nations New York, 2009, ISBN 978-92-1-130278-3
} 


\section{Poverty in India}

India ranked 162 GNI Per Capita with 1410 US Dollars in 2011 and is named as lower middle income country ${ }^{4}$ under altas method and is ranked 156 with under PPP method an GNI Per Capita of 3590 International Dollars in 2011. Poverty in India is widespread, with the nation estimated to have a third of the world's poor. In 2010, the World Bank reported that $32.7 \%$ of the total Indian people falls below the international poverty line of US\$ 1.25 per day while $68.7 \%$ live on less than US\$2 per day. ${ }^{5}$

Poverty in India is mainly due to lack of proper government policies and the exploitation of the financially weaker section by the richer class. The main outcome of poverty is hunger. Hunger's seriousness can be understood easily from the fact that every year, 5.8 million children die from hunger related-causes around the world. (That is, 16,000 children die each day) ${ }^{6}$

Estimates by NCAER (National Council of Applied Economic Research) show that 80 million households in India are in income levels of Rs. 45,000-90,000 per year. These numbers also are more or less in line with the latest World Bank's estimates of the "below-the-poverty-line" households that may total about 456 million individuals. ${ }^{7}$

In 1947, the average annual income in India was US\$ 619, compared with US\$ 439 for China, US\$ 770 for South Korea, and US \$936 for Taiwan. But, by 1999, the average annual income became US\$1,818 for India; US\$ 3,259 for China; US\$13,317 for South Korea and US\$ 15,720 for Taiwan ${ }^{8}$

\section{Poverty Line}

Poverty is normally defined with respect to poverty line. Poverty line is a cut-off point on the line of distribution which divides the population as poor and non-poor. There is a huge discrepancy in fixing the poverty line in our country. The World Bank has fixed the international poverty line as US $\$ 1.25$ per day while the World Health Organization considers people living below US \$2 a day as poor. According to the latest data, the number of people living below the international poverty line in 2005 was 1.4 billion, or close to 500 million?.

The 'dollar-a-day poverty line' has its roots in the purchasing power parity (PPP) exchange rates generated by the International Comparison Program project, undertaken jointly by the United Nations Statistics Division, the World Bank and the University of Pennsylvania. The PPPs were used first to construct an "average" poverty line for a group of countries for which the International Comparison Program provided information and then to convert this common line into national currencies in order to estimate the incidence of poverty using national distributional data. The Program has produced three rounds of estimates: in 1985, when the Program covered 22 countries, with a poverty line of \$1 per person per day; in 2000-2001, when the estimates were revised using the PPP exchange rates of the Program's 1993 round with a poverty line of $\$ 1.08$ per person per day; and in 2005, when the Program produced new estimates using its 2005 PPPs, with the poverty line raised to $\$ 1.25$ per person per day. Each subsequent round leads to a re-estimation of the incidence of poverty.

The poverty line in India was originally fixed in terms of income/food requirements in 1978. It was stipulated that the calorie standard for a typical individual in rural areas was 2400 calorie and was 2100 calorie in urban areas. Then the cost of the grains (about $650 \mathrm{gms}$ ) that fulfil this normative standard was calculated. This cost was the poverty line. In 1978, it was Rs.61.80 per person per month for rural areas and

\footnotetext{
${ }^{4}$ World Development Indicators database, World Bank. http://databank.worldbank.org/databank/download/GNIPC.pdf

5 "India - New Global Poverty Estimates", World Bank

${ }^{6}$ FAO Hunger Report 2008

7 http://www.ncaer.org/downloads/MediaClips/Press/businesstandard-arvindsingal.pd

8 Meghnad Desai (2003), "India and China: An Essay in Comparative Political Economy", IMF

${ }^{9}$ Rethinking Poverty, Report on the World Social Situation 2010, Department of Economic and Social Affairs, United Nations publication, United Nations New York, 2009, ISBN 978-92-1-130278-3
} 
Rs.71.30 for urban areas. Since then the Planning Commission calculates the poverty line every year adjusting for inflation. The Indian Planning Commission has taken efforts to reduce the number of people living below poverty line by reducing the standards from the international $\$ 1.25$ per day to $\$ 0.50$ a day instead of improving their standard of living. However, recently, after a lot of criticism, the poverty line had been increased to about a dollar per day (Rs. 65) in urban areas and a little lesser (Rs. 50) in the rural areas $^{10}$. This income is the bare minimum to support the food requirements and does not provide much for the other basic essential items like health, education etc. That is why some times the poverty lines have been described as starvation lines.

\begin{tabular}{|l|c|c|c|}
\hline \multicolumn{4}{|c|}{ Proportion of the population living on less than $\$ 1.25$ a day in countries of South Asia (\%) } \\
\hline Country & 1981 & 1990 & 2005 \\
\hline Nepal & No data & 77 & 54.7 \\
\hline Bangladesh & 44.2 & 49.9 & 50.5 \\
\hline India & 59.8 & 51.3 & 41.6 \\
\hline Bhutan & 47.4 & 51 & 26.8 \\
\hline Pakistan & 72.9 & 58.5 & 22.6 \\
\hline China & 84.0 & 60.2 & 15.9 \\
\hline Sri Lanka & 31 & 15 & 10.3 \\
\hline \multicolumn{4}{|l}{ Source: World Bank, Development Research Group (2009) } \\
\hline
\end{tabular}

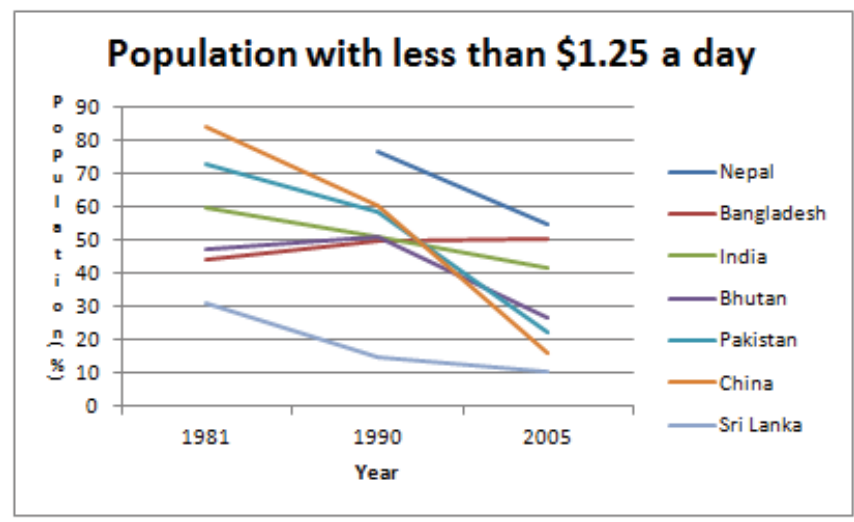

The above table shows the Percentage of the population living on less than $\$ 1.25$ a day in countries of South Asia. The reduction in poverty is extremely significant in China followed by Bhutan and Nepal. Poverty has increased in Nepal while very less decrease in poverty is seen in the other countries including India.

\section{The Global Hunger Index of India}

The Global Hunger Index is calculated by the International Food Policy Research Institute (IFPRI), The Food and Agriculture Organization (FAO) of the United Nations. The GHI ranks countries on a 100-point scale. Zero is the best score (no hunger), while 100 is the worst, although neither of these extremes has been reached practically.

The Global Hunger Index (GHI) combines three equally weighted indicators into an index number to reflect the multidimensional nature of hunger. The indicators are:

1. Undernourishment: The proportion of undernourished as a percentage of the population (reflecting

10 The Hindu dated 25-7-2013 page 1. 
the share of the population with insufficient calorie intake);

2. Child underweight: The proportion of children younger than the age of five who are underweight (low weight for age reflecting wasting, stunted growth, or both), which is one indicator of child under nutrition; the prevalence of underweight children under the age of five.

3. Child mortality: The mortality rate of children younger than the age of five (partially reflecting the fatal synergy of inadequate dietary intake and unhealthy environments).

The Global hunger index is calculated as follows:

Global Hunger Index GHI = (PUN + CUW + CM) /3

- PUN: proportion of the population that is undernourished (in \%)

- CUW: prevalence of underweight in children younger than five (in \%)

- CM: proportion of children dying before the age of five (in \%)

Values less than 4.9 reflect "low hunger", values between 5 and 9.9 reflect "moderate hunger", values between 10 and 19.9 indicate a "serious" hunger problem, values between 20 and 29.9 indicate an "alarming" hunger problem, and values exceeding 30 indicate "extremely alarming" hunger problem.11

To know the status of India in the regional level, an inter-country study has been attempted here. India and its few neighbours' hunger index are studied. The countries taken into consideration are Bangladesh, India, Nepal, Pakistan, Sri Lanka and China.

\begin{tabular}{|l|c|c|c|c|}
\hline \multicolumn{5}{|c|}{ Global Hunger Index of India and Neighbouring Countries } \\
\hline & 1990 & 1996 & 2001 & 2012 \\
\hline & $\begin{array}{c}\text { (with data from } \\
1988-92)\end{array}$ & $\begin{array}{c}\text { (with data from } \\
1994-98)\end{array}$ & $\begin{array}{c}\text { (with data from 1999- } \\
\text { (2003) }\end{array}$ & $\begin{array}{c}\text { (with data from 2005- } \\
2010)\end{array}$ \\
\hline Bangladesh & 37.9 & 36.1 & 27.8 & 24 \\
\hline India & 30.3 & 22.6 & 24.2 & 22.9 \\
\hline Nepal & 26.9 & 24.4 & 23 & 20.3 \\
\hline Pakistan & 25.5 & 21.8 & 21.7 & 19.7 \\
\hline Sri Lanka & 20.8 & 18.4 & 15.2 & 14.4 \\
\hline China & 11.8 & 8.9 & 6.7 & 5.1 \\
\hline $\begin{array}{l}\text { Source: Global hunger Index 2012 International Food Policy and Research Institute and Welthungerhilfe and } \\
\text { Green Scenery and Concern Worldwide }\end{array}$ \\
\hline
\end{tabular}

There is a considerable reduction of hunger rate in all the countries on the whole. However, no country has come under the extreme categories of 'low' hunger problems and 'extremely alarming' hunger problems. China is the only country in the region with 'moderate' hunger problems. Sri Lanka and Pakistan have 'serious' hunger problems. Nepal, India and Bangladesh have 'alarming' hunger problems. India stands in the $14^{\text {th }}$ position from the last out of the 130 countries under the $\mathrm{GHI}$.

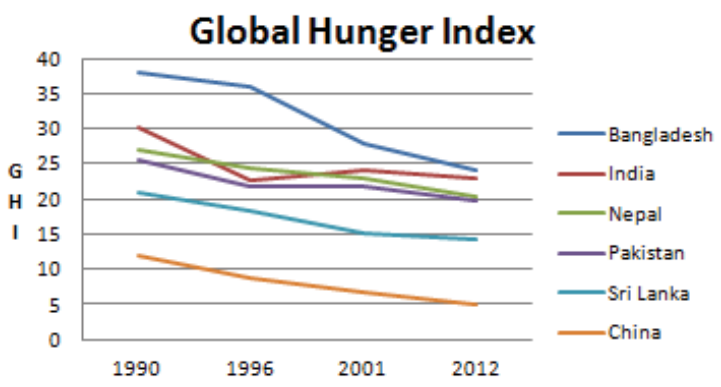

${ }^{11}$ Global hunger Index 2012 International Food Policy and Research Institute and Welthungerhilfe and Green Scenery and Concern Worldwide 
From the above table and line chart, it is clear that Bangladesh ranks the lowest among the countries taken into consideration based on the hunger index even though it shows good improvement. India's record shows unsteady trend and has not shown much improvement. Nepal, Pakistan and Sri Lanka also show slight decrease in hunger index. The hunger level in China is remarkably low compared to the other countries taken into consideration.

\section{Multidimensional Poverty Index of India}

The Multidimensional Poverty Index or MPI is an international poverty measure developed by the Oxford Poverty and Human Development Initiative (OPHI) for the United Nations Development Programme's flagship Human Development Report in 2010.

The MPI is calculated using the formula, ${ }^{12} \mathrm{MPI}=\mathrm{HXA}$

$\mathrm{H}$ - Percentage of people who are MPI poor (incidence of poverty)

A - Average intensity of MPI poverty across the poor (\%)

Multidimensional Poverty Index in India 13

- Multidimensional Poverty Index - 0.296

- Number of MPI Poor People (in millions) - 645

- Total Population (in millions) - 1164.7

- Percentage of people with Income less than $\$ 1.25$ a day - $42 \%$

- Percentage of people with Income less than $\$ 2$ a day - 76\%

- Percentage of people with Income less than National Poverty Line - 29\%

- Human Development Index - $0.5544^{14}$

- HDI rank (186 countries) 136

\begin{tabular}{|l|c|c|}
\hline \multicolumn{3}{|c|}{ Multidimensional Poverty across Indian States ${ }^{15}$} \\
\hline & MPI & Proportion of Poor \\
\hline Kerala & 0.065 & $15.9 \%$ \\
\hline Goa & 0.094 & $21.7 \%$ \\
\hline Punjab & 0.120 & $26.2 \%$ \\
\hline Himachal Pradesh & 0.131 & $31.0 \%$ \\
\hline Tamil Nadu & 0.141 & $32.4 \%$ \\
\hline Uttaranchal & 0.189 & $40.3 \%$ \\
\hline Maharashtra & 0.193 & $40.1 \%$ \\
\hline Haryana & 0.199 & $41.6 \%$ \\
\hline Gujarat & 0.205 & $41.5 \%$ \\
\hline Jammu And Kashmir & 0.209 & $43.8 \%$ \\
\hline Andhra Pradesh & 0.211 & $44.7 \%$ \\
\hline Karnataka & 0.223 & $46.1 \%$ \\
\hline Eastern Indian States & 0.303 & $57.6 \%$ \\
\hline West Bengal & 0.317 & $58.3 \%$ \\
\hline Orissa & 0.345 & $64.0 \%$ \\
\hline Rajasthan & 0.351 & $64.2 \%$ \\
\hline
\end{tabular}

\footnotetext{
${ }^{12}$ Alkire Roche Santos Seth, 'Multidimensional Poverty Index 2011: Brief Methodological Note', Oxford Poverty \& Human Development Initiative (OPHI)

${ }^{13}$ Human Development Report 2009, Statistical Annex L

14 Human Development Report 2013

${ }^{15}$ Country Briefing India, Multidimensional Poverty Index (MPI) At a Glance July 2010 Oxford Poverty and Human Development Initiative (OPHI), Oxford Dept of International Development, Queen Elizabeth House, University of Oxford
} 


\begin{tabular}{|c|c|c|}
\hline Uttar Pradesh & 0.386 & $69.9 \%$ \\
\hline Chhattisgarh & 0.387 & $71.9 \%$ \\
\hline Madhya Pradesh & 0.389 & $69.5 \%$ \\
\hline Jharkhand & 0.463 & $77.0 \%$ \\
\hline Bihar & 0.499 & $81.4 \%$ \\
\hline & 0.296 & $55.4 \%$ \\
\hline
\end{tabular}

81.4 percent of the population in Bihar are multidimensional poor. Uttar Pradesh is the home of largest number of poor people - 21 percent of India's poor people live here. The multidimensional poverty is lowest for Kerala. The top five states home only 4.5 percent of the poor, whereas, the five poorest states home more than 50 percent of the poor people.

\section{Deprivation of each Indicator of MPI in India ${ }^{16}$}

The MPI uses 10 indicators to measure poverty in three dimensions. The percentages given represent the level of deprivation of that indicator in India.

\subsection{Education}

1. Schooling - $17.6 \%$ (no household member has completed five years of schooling)

2. Enrolment $-25.0 \%$ (any school-aged child is not attending school up to class 8 )

\subsection{Health}

1. Child Mortality - $23 \%$ (any child has died in the family)

2. Nutrition - $38.9 \%$ (any adult or child is malnourished)

\subsection{Living Standard}

3. Electricity $-28.7 \%$ (the household has no electricity

4. Sanitation $-49.3 \%$ (the household's sanitation is not acc. to MDG guidelines or the facility is shared with other houses)

5. Drink. Water - $12 \%$ (the household does not have access to safe drinking water or it is available at more than a 30-minute walk roundtrip

6. Floor $-40.0 \%$ (the household has a dirt, sand or dung floor)

7. Cooking Fuel $-52.2 \%$ (the household cooks with dung, wood or charcoal)

8. Assets $-38.1 \%$ (the household does not own more than one radio, TV, telephone, bike, motorbike or refrigerator and does not own a car or truck) ${ }^{17}$

A person is considered poor if he is deprived in at least $33.33 \%$ of the weighted indicators. The intensity of poverty denotes the proportion of indicators in which they are deprived.

${ }^{16}$ Country Briefing India, Multidimensional Poverty Index (MPI) At a Glance July 2010 Oxford Poverty and Human Development Initiative (OPHI), Oxford Dept of International Development, Queen Elizabeth House, University of Oxford ${ }_{17}$ Country Briefing India, Multidimensional Poverty Index (MPI) At a Glance July 2010 Oxford Poverty and Human Development Initiative (OPHI), Oxford Dept of International Development, Queen Elizabeth House, University of Oxford 


\section{Conclusion}

All the poverty indicators show that India is in a difficult situation. In fact, the entire South Asian region has to improve a lot. The reduction in poverty, especially in Bangladesh and India, from the data analysed under the WHO's poverty line is very slow. The Global Hunger Index and the Multidimensional Poverty Index ranking coupled together shows that India is very backward compared to the other western and Far East countries. Unless strong and immediate measures are taken in large and small scale, the poverty in India will become unrestrained. So, the government has to bring about valuable changes in its policy structures and its implementation.

\section{References}

http://www.ifpri.org/book-8018/node/8058

http://www.countrystat.org/

Global hunger Index 2012 International Food Policy and Research Institute and Welthungerhilfe and Green Scenery and Concern Worldwide

http://www.ifpri.org/book-8018/node/8058

Bavadam, Lyla(10 April 2010). "No jobs, no food". Frontline, Volume 24, Issue 8, (Chennai: The Hindu). pp. Cover Story. Retrieved 2010-09-29.

Oxford Poverty \& Human Development Initiative

Global Hunger Index, The Challenge of Hunger 2008, International Food Policy and Research Institute and Welthungerhilfe and Green Scenery and Concern Worldwide

http://www.ifpri.org/book-8018/node/8058

'A wealth of data. A useful new way to capture the many aspects of poverty' - The Economist, July 29, 2010. Retrieved 2010-08-04

Global Hunger Index 2012, International Food Policy and Research Institute and Welthungerhilfe and Green Scenery and Concern Worldwide

http://www.ncaer.org/downloads/MediaClips/Press/businesstandard-arvindsingal.pdf

Rethinking Poverty, Report on the World Social Situation 2010, Department of Economic and Social Affairs, United Nations publication, United Nations New York, 2009, ISBN 978-92-1-130278-3

The Global Competitiveness Report 2012-2013

Megnnad Desai (2003), 'India and China: An essay in Comparative Political Economy', IMF

Country Briefing India, Multidimensional Poverty Index (MPI) At a Glance July 2010 Oxford Poverty and Human Development Initiative (OPHI), Oxford Dept of International Development, Queen Elizabeth House, University of Oxford

IFPRI/ Concern/ Welthungerhilfe: 2012 Global Hunger Index - The challenge of hunger: Ensuring sustainable food security under land, water, and energy stresses. Bonn, Washington D. C., Dublin. October 2012.

Alkire Roche Santos Seth, 'Multidimensional Poverty Index 2011: Brief Methodological Note', Oxford Poverty \& Human Development Initiative (OPHI) 
